\title{
0 potrzebie stworzenia polskiego rejestru chorych na stwardnienie rozsiane
}

\section{Need for creating Polish registry of multiple sclerosis patients}

\author{
Waldemar Brola', Małgorzała Fudala', Stanisław Flaga'2, Danuta Ryglewicz ${ }^{3}$ \\ 1Oddział Neurologii z Oddziałem Udarowym Szpitala Specjalistycznego w Końskich \\ 2Akademia Górniczo-Hutnicza w Krakowie \\ 3) Klinika Neurologiczna, Instyłut Psychiatrii i Neurologii w Warszawie
}

Neurologia i Neurochirurgia Polska 2013; 47, 5: 484-492

DOI: 10.5114/ninp.2013.38228

\section{Streszczenie}

Stwardnienie rozsiane (SR) jest najczęstszą przyczyną niesprawności neurologicznej młodych osób. Szacuje się, że na SR choruje ok. 40 000-60 000 osób w skali całego kraju, a rocznie stwierdza się ok. 2000 nowych zachorowań. Dane te są jednak szacunkowe i wymagają weryfikacji badaniami obejmującymi populację całego kraju. Dotychczas opublikowane wyniki dotyczą tylko niektórych regionów Polski. Konieczne jest również precyzyjne określenie potrzeb pacjentów w zakresie leczenia immunomodulującego i przeprowadzenie szczegółowych analiz farmakoekonomicznych. W celu oszacowania podstawowych parametrów epidemiologicznych, wzorem wielu krajów, potrzebne jest powołanie narodowego rejestru chorych na stwardnienie rozsiane, skupiającego wokół tego projektu wszystkie ośrodki zajmujące się leczeniem SR. $\mathrm{W}$ artykule przedstawiono najważniejsze europejskie i amerykańskie bazy danych oraz przybliżono założenia polskiego Rejestru Chorych ze Stwardnieniem Rozsianym - REJSM, już funkcjonującego w jednym $z$ województw.

Słowa kluczowe: stwardnienie rozsiane, epidemiologia, rejestr chorych.

\section{Wstęp}

Stwardnienie rozsiane (SR) jest postępującą, zapalno-demielinizacyjną chorobą ośrodkowego układu nerwowego o nieznanej etiologii [1]. W patogenezie pod-

\begin{abstract}
Multiple sclerosis (MS) is the most common cause of neurological disability of young people. It is estimated that 40 000-60 000 people in the country suffer from MS, and approximately 2000 new cases are diagnosed annually. These are, however, estimated data and require verification by nation-wide research. Results published so far concern only certain regions of Poland. It is also vital to precisely describe the needs of patients in terms of immunomodulating treatment and to perform detailed pharmacoeconomical analysis. In order to estimate basic epidemiological parameters there is a need of creating, in imitation of many other countries, a national register of MS patients which would concentrate all assets concerning MS around this project. The article presented the most important of American and European databases and explained the basis of the Polish register of MS patients, which is already functioning in one of the regions.
\end{abstract}

Key words: multiple sclerosis, epidemiology, patients registry.

stawową rolę odgrywa proces autoimmunologiczny przy współudziale czynników egzogennych, środowiskowych oraz predyspozycji genetycznej. Znamienną cechą choroby jest obecność rozsianych ognisk demielinizacji, umiejscowionych przede wszystkim w istocie białej

Adres do korespondencii: dr n. med. Waldemar Brola, Oddział Neurologii, Szpital Specjalistyczny im. św. Łukasza, ul. Gimnazjalna 41 B, 26-200 Końskie, tel. +484139022 59,6013134 15, faks: +48413902364,e-mail:wbrola@wp.pl

Prace otrzymano: 7.10.2012, przyięto do druku: 11.12 .2012 
mózgu, najczęściej przykomorowo. Choroba rozpoczyna się zazwyczaj pomiędzy 20. a 40. rokiem życia, co powoduje, że SR jest jedną z najczęstszych przyczyn niesprawności wśród młodych osób. Liczba chorych na całym świecie przekracza 2,5 mln, z czego ok. 600 tys. żyje w Europie [2]. Ocenia się, że częstość występowania SR w Polsce wynosi od 45 do 92 przypadków na 100 tys. mieszkańców [3,4]. Szacuje się, że na SR choruje ok. 60 tys. osób w skali całego kraju, ale jak podaja inni autorzy, a szczególnie Potemkowski, gdyby ta liczba była realna, chorobowość musiałaby wynosić 150 na 100 tys. mieszkańców [4-10]. Rocznie stwierdza się ok. 2 tys. nowych zachorowań (według symulacyjnych danych od 1100 do 1700 nowych przypadków) [4]. Dane te sa jednak tylko szacunkowe i niepoparte żadnymi badaniami obejmującymi populację całego kraju. Dotychczas opublikowane badania epidemiologiczne dostarczają jedynie fragmentarycznych danych z niektórych regionów Polski [5-11].

W ciagu ostatnich lat wprowadzono nowe metody leczenia, do których dostęp powinien być zabezpieczony dla wszystkich potrzebujących. Polska pozostaje jedynym krajem w Europie, który nie ma programu kompleksowej pomocy chorym na SR. Konieczne jest precyzyjne określenie potrzeb pacjentów w zakresie leczenia immunomodulującego (kwalifikacja do programów terapeutycznych Narodowego Funduszu Zdrowia), jak również przeprowadzenie szczegółowych analiz farmakoekonomicznych.

W celu oceny sytuacji epidemiologicznej w Polsce, wzorem wielu krajów, potrzebne jest powołanie narodowego rejestru chorych na stwardnienie rozsiane, skupiającego wokół tego projektu wszystkie ośrodki zajmujące się leczeniem SR. Opracowana w ten sposób baza danych umożliwi dokładne oszacowanie potrzeb chorych na SR i realizację odpowiednich świadczeń.

$\mathrm{W}$ artykule przedstawiono niektóre narodowe i międzynarodowe rejestry chorych na SR oraz przybliżono założenia polskiej regionalnej bazy danych, już funkcjonującej w jednym $z$ województw.

\section{Rejestry skandynawskie}

Kraje skandynawskie charakteryzują się wysokimi wskaźnikami rozpowszechnienia SR i dobrze rozwinięta opieką socjalną, dlatego już od wielu lat prowadzą systematyczne badania epidemiologiczne. $Z$ reguły projekty te finansowane są przez organizacje rządowe lub narodowe fundacje. Zbieranie danych ułatwia fakt, że liczba ludności w poszczególnych krajach Skandynawii rzad- ko przekracza 5 mln (z wyjątkiem prawie 10-milionowej populacji Szwecji).

Duński rejestr chorych na SR (Danish MS Registry), najstarszy $z$ omawianych, funkcjonuje od 1 stycznia 1948 r. [12]. Został powołany do rejestracji i długotrwałej obserwacji chorych $z$ pewnym lub prawdopodobnym SR zamieszkujących terytorium Danii. Jego celem jest oszacowanie rozpowszechnienia $\mathrm{i}$ innych wskaźników epidemiologicznych SR, aspektów geograficznych i zmienności w czasie w zależności od wieku i płci. Od 1986 r. jest afiliowany przy Narodowym Instytucie Zdrowia Publicznego i uznawany za rejestr narodowy. Zawiera informacje o pierwszych objawach, roku zachorowania, roku ustalenia rozpoznania i kryteriach diagnostycznych. Wszystkie wprowadzane dane są na bieżąco weryfikowane przez 2 neurologów i 3 statystyków. Informacje o wywiadzie rodzinnym i stanie niesprawności są nieobowiązkowe i dostępne tylko w niektórych przypadkach [13,14]. Źródło informacji stanowia wszystkie 22 oddziały i kliniki neurologiczne w Danii, ośrodki rehabilitacji, Duńskie Towarzystwo Stwardnienia Rozsianego (Danish MS Society), prywatnie praktykujący neurolodzy, lekarze ogólni i Narodowy Rejestr Pacjentów (National Patient Registry), który dostarcza ogólnych danych o osobach hospitalizowanych od 1977 r. Obecnie w bazie danych jest ponad 20 tys. pacjentów z pewnym SR, co stanowi 90-95\% szacowanej liczby chorych [15].

W momencie wprowadzenia w 1996 r. leczenia immunomodulującego utworzono dodatkowy rejestr Danish MS Treatment Registry - obejmujący pacjentów otrzymujących takie leczenie. Rejestr zawiera aktualizowane co 6 miesięcy dane dotyczace badania neurologicznego, podstawowych testów laboratoryjnych, liczby i ciężkości rzutów, oceny niesprawności w skali Expanded Disability Status Scale (EDSS), efektów ubocznych i obecności przeciwciał neutralizujących. Obecnie w tej bazie zarejestrowanych jest ponad 4 tys. osób [16].

Norweski Narodowy Rejestr Stwardnienia Rozsianego (Norwegian National MS Registry) powstał pod auspicjami Ministerstwa Zdrowia i Spraw Socjalnych na wniosek Norweskiego Towarzystwa Neurologicznego [17]. W 1996 r. powołano narodowe centrum SR $\mathrm{z}$ siedzibą w Haukeland University Hospital w Bergen. Jego zadaniem było stworzenie infrastruktury programu rejestrującego chorych na SR z terenu całej Norwegii, który byłby dotowany przez Ministerstwo Zdrowia. Program rozpoczął działalność w 2001 r. Warunkiem koniecznym rejestracji jest uzyskanie pisemnej zgody od każdego pacjenta. Zbierane dane dotyczą wieku, płci, 
początku choroby i objawów, wyników badań diagnostycznych, przebiegu choroby, przypadków rodzinnych i innych chorób przewlekłych. Dane te są przesyłane do centrum w Bergen, gdzie po opracowaniu wprowadza się je do bazy. Do 2006 r. zarejestrowano ponad 3300 pacjentów, co stanowi wg danych szacunkowych 50-60\% wszystkich chorych na SR [17]. Założeniem projektu jest rejestracja całej populacji chorych, ale zadanie to znacznie utrudnia wymóg pisemnej zgody każdego pacjenta. W ostatnich latach rozszerzono zakres działania o nowe jednostki zajmujące się gromadzeniem materiału biologicznego od chorych (płynu mózgowo-rdzeniowego, surowicy, DNA i tkanek) i zmieniono nazwę rejestru na Norwegian MS Register and Biobank [17].

Szwedzki rejestr SR (Swedish National MS Registry) funkcjonuje od 1997 r. i jest również dotowany przez agencję rządową (National Board of Health and Welfare) [18]. Jego założeniem jest oszacowanie potrzeb i jakości opieki zdrowotnej nad chorymi na SR oraz ocena sytuacji epidemiologicznej. Rejestracja odbywa się drogą elektroniczną, a dane mogą wprowadzać wszyscy lekarze zajmujący się leczeniem SR. Każdy lekarz biorący udział w projekcie ma wgląd do swoich danych i ogólnych informacji o całej populacji chorych z terenu Szwecji [18]. Do 2009 r. w bazie było zarejestrowanych ponad 10 tys. pacjentów, co stanowiło $75 \%$ szacowanej liczby chorych na SR [19].

\section{Italian MS Database Network}

Włoski rejestr chorych na SR (Multiple Sclerosis Database Network - MSDN) oparty jest na elektronicznym systemie monitoringowym iMED ${ }^{\circledR}$ udostępnianym przez Serono International Foundation [20]. Na podstawie klucza geograficznego wyselekcjonowano 26 ośrodków mających największe doświadczenie w le czeniu SR. W 1996 r. opracowano jednolity standaryzowany protokół zbierania danych, zaaprobowany przez włoskie Ministerstwo Zdrowia. Każdy z uczestniczących w projekcie ośrodków przeszedł szkolenie dotyczące kryteriów rozpoznawania, leczenia, oceny chorych oraz sposobu gromadzenia i wprowadzania danych do systemu iMED. Ponadto każdy z ośrodków otrzymał pełne wyposażenie komputerowe $z$ łączem ISDN, oprogramowaniem iMED, a personel dostaje stosowną gratyfikację za swoją pracę. Za jakość i spójność wprowadzanych danych w każdym z ośrodków odpowiedzialny jest neurolog monitorujący. Anonimowe dane pacjentów są wysyłane do serwera centralnego i tam poddawane analizie epidemiologicznej.
Zbieranie danych rozpoczęto 1 stycznia 2001 r., a w lutym 2003 r. było już zarejestrowanych 10078 osób z klinicznie pewnym SR oraz odosobnionym zespołem klinicznym (clinically isolated syndrome - CIS), zarówno leczonych, jak i nieleczonych [21]. Dane uzupełniane są systematycznie i obejmują przynajmniej jedną wizytę w roku z oceną niesprawności w skali EDSS, liczby rzutów i rodzaju stosowanego leczenia [20-22].

\section{Rejestr niemiecki}

W latach 90. ubiegłego wieku na terenie Niemiec działało kilka lokalnych rejestrów SR: MUSIS (Multiple Sclerosis Information System), SMile-Card oraz TQMS Promise (Total Quality Management in der Versorgung von MS-Patienten Praxis-orientiertes Multiple Sklerose Informations-System) [23-25]. Funkcjonowały one jednak tylko w ośrodkach uniwersyteckich i nigdy nie upowszechniły się w skali całego kraju.

W 2001 r. pod auspicjami Niemieckiego Towarzystwa SR zainicjowano pracę nad narodowym, ujednoliconym programem zbierania danych ze wszystkich klinik, lokalnych szpitali, centrów rehabilitacji i od lekarzy praktykujących prywatnie. Opracowano tzw. Minimal Data Set, czyli pakiet niezbędnych informacji wymaganych do zarejestrowania chorego (wiek, płeć, czas pojawienia się pierwszych objawów, czas postawienia diagnozy, postać i aktywność choroby, stopień niesprawności, leczenie immunomodulujące i objawowe oraz dane socjoekonomiczne: wykształcenie, zatrudnienie, świadczenia socjalne). Dane zbierane w każdym z ośrodków są kodowane - nie podaje się nazwisk i dat urodzenia, każdemu pacjentowi przypisuje się 32-literowy pseudonim a następnie zapisywane na nośniku cyfrowym i raz na kwartał przesyłane do centrum MSFP (MS Forschungsund Projektentwicklungs). Tam poddawane są weryfikacji pod względem kompletności i spójności, przechowywane, aktualizowane i opracowywane epidemiologicznie $[26,27]$.

Pilotażową fazę rejestru rozpoczęto 1 stycznia $2002 \mathrm{r}$. w 5 ośrodkach różniących się poziomem świadczonych usług (szpital uniwersytecki, klinika neurologiczna, szpital lokalny i prywatnie praktykujący neurolodzy). Po 2 latach przeanalizowano jakość wprowadzanych danych i zmodyfikowano nieznacznie zakres niezbędnych informacji, które muszą się znaleźć w Minimal Data Set. Od marca 2005 r. kolejne niemieckie ośrodki zaczęły gromadzenie danych. W 2008 r. zaangażowanych było już 101 ośrodków, które zebrały dane dotyczące 10924 pacjentów [27]. 


\section{Rejestry amerykańskie}

W Kanadzie i Stanach Zjednoczonych, krajach o du żym rozpowszechnieniu $\mathrm{SR}$, nie są prowadzone rejestry narodowe, funkcjonuje natomiast wiele regionalnych baz danych. Najstarszym rejestrem kanadyjskim jest London, Ontario Database, funkcjonujący już od 1972 r. Zgromadzone dane dotyczą prowincji Ontario, najprężniejszej ekonomicznie i najludniejszej w Kanadzie, zamieszkałej przez ok. $12 \mathrm{mln}$ ludzi. Rejestrem objętych jest ponad 5 tys. pacjentów z SR, co stanowi prawie $90 \%$ szacowanej liczby chorych, a dane wszystkich pacjentów są każdego roku aktualizowane [28-30].

W 1980 r. na University of British Columbia (UBC) w Kanadzie rozpoczęła działanie komputerowa baza danych MS Costar (MS Computer Stored Ambulatory Record). Baza zawierała dane ponad 6 tys. pacjentów, z czego ok. 4 tys. aktywnych [31,32]. Długoterminowe badania kontrolne były prowadzone przez ponad 20 lat przez główną klinikę uniwersytetu i dwa satelitarne ośrodki. Po unowocześnieniu technologii dołączono 2 kolejne ośrodki leczenia SR i zmieniono nazwę rejestru na British Columbia Multiple Sclerosis Database (BCMS). Szacuje się, że rejestrem objętych jest prawie $80 \%$ wszystkich pacjentów z SR zamieszkujących prowincję Kolumbia Brytyjska. Jest on bardzo wszechstronny, gdyż może służyć jednocześnie jako karta pacjenta i narzędzie badawcze. Pozwala na wprowadzenie wizyt pacjenta, rozmów telefonicznych, każdorazowego badania neurologicznego, wcześniejszego wywiadu w czasie niezależnym od czasu wizyty. Wprowadzone wcześniej dane można uzyskać w postaci podsumowania zawierającego komplet poszukiwanych informacji (np. badanie neurologiczne) w porządku chronologicznym. Dane aktualizowane są przynajmniej raz w roku $[29,30]$.

W Stanach Zjednoczonych Ameryki Północnej funkcjonuje kilka regionalnych rejestrów. Do najbardziej znanych należą: New York State Multiple Sclerosis Consortium, NARCOMS MS Registry i Departament of Veterans Affairs MS Registry [30,33-35].

W 1996 r. North-American Consortium of MS Centers zainicjowało działalność NARCOMS (North American Research Committee on Multiple Sclerosis). Założeniem tego długoterminowego projektu jest promowanie oraz realizacja badań klinicznych i epidemiologicznych nad SR. NARCOMS to rejestr internetowy, do którego dane przez stronę www.narcoms.org wprowadzają sami pa cjenci. Po dobrowolnej rejestracji i podpisaniu zgody na udział w badaniu pacjent jest zobowiązany do systematycznego raportowania informacji dotyczących przebie- gu choroby. Co 6 miesięcy drogą internetową otrzymuje kwestionariusz, w którym zapisuje wszystkie zmiany w stanie zdrowia i leczeniu. Pytania dotyczą danych demograficznych, ubezpieczenia zdrowotnego, historii choroby, leczenia immunomodulującego i objawowego, niepełnosprawności i jakości życia oraz otrzymywanej pomocy społecznej [33]. Na podstawie przebiegu choroby i występowania rzutów w roku poprzedzającym u chorego rozpoznaje się odpowiednią postać SM. Niesprawność oceniana jest według 2 skal - Patient-Determined Disease Steps (PDDS) i Performance Scale, które wykazują bardzo dużą korelację z oceną EDSS [33-35]. $\mathrm{W}$ ocenie jakości życia stosuje się powszechnie znany kwestionariusz samooceny SF-12. Sukcesywnie dodawane są kolejne kwestionariusze (oceny bólu, drżenia, zmęczenia), a rejestr stał się dostępny dla zainteresowanych z całego świata i zyskał zasięg globalny. Od momentu rozpoczęcia zbierania danych do września 2012 r. zarejestrowanych było ponad 35 tys. pacjentów [36].

Rejestr New York State Multiple Sclerosis Consortium (NYSMSC) również rozpoczął działanie w 1996 r. Jego głównym celem jest gromadzenie danych demograficznych i klinicznych w celu promowania badań dotyczących SR i poprawy opieki nad chorymi [37]. W rejestrze uczestniczy 15 ośrodków neurologicznych ze stanu Nowy Jork, które posługują się wystandaryzowanym, jednolitym protokołem. Informacje są zbierane zarówno od lekarzy, jak i pacjentów i dotyczą danych demograficznych, wykształcenia, środowiska życia, zatrudnienia, wywiadu rodzinnego, niesprawności funkcjonalnej, jakości życia, danych związanych z przebiegiem choroby, charakterystyki psychologicznej i aktualnie stosowanego leczenia [37]. Do 2006 r. zarejestrowano ponad 9 tys. chorych na SR $[29,37]$.

Rejestr Departamentu ds. Weteranów (Department of Veterans Affairs MS Centers of Excellence) opiera się na Międzynarodowej Klasyfikacji Chorób (ICD-9-CM). Pacjenci są włączani do rejestru na podstawie kodu SR. W latach 1998-2006 zarejestrowano ponad 32 tys. pacjentów, z czego pewne rozpoznanie potwierdzono u 17400 osób. Dane w większości dotyczą mężczyzn i nie zawierają informacji o wieku, początku choroby, EDSS ani postaci klinicznej choroby [29].

Oprócz wspomnianych rejestrów istnieją jeszcze pomniejsze, np. Oregon MS Registry czy Pacific-Northwest MS Registry, ale brakuje rejestru ogólnokrajowego. $\mathrm{W}$ ostatnim czasie trwaja jednak intensywne prace, przy poparciu Narodowego Instytutu Zdrowia i Kongresu Stanów Zjednoczonych, nad stworzeniem National Multiple Sclerosis Disease Registry [29]. 


\section{Rejestr brytyjski}

Bardzo ciekawym i najświeższym pomysłem jest projekt brytyjski nazwany UK MS Register [38]. Po szerokiej kampanii reklamowej w prasie, radiu i telewizji, w maju $2011 \mathrm{r}$. ruszył portal internetowy pod adresem www.ukmsregister.org. Rejestr powstał dzięki wspólnej inicjatywie towarzystw stwardnienia rozsianego Anglii, Szkocji, Walii i Irlandii Północnej, a jego centrum znajduje się w walijskim Swansea University. W rejestrze mogą wziąc udział wszyscy pełnoletni chorzy, którzy po zalogowaniu samodzielnie odpowiedzą na pytania dotyczące danych demograficznych, wykształcenia, zatrudnienia, początku i przebiegu choroby, rodzaju leczenia oraz wypełnią standaryzowane kwestionariusze dotyczące wpływu choroby, lęku i depresji, samopoczucia, zmęczenia i jakości życia [38]. Każdy zarejestrowany uczestnik co 3 miesiące otrzymuje e-mail z prośbą o aktualizację danych i ponowne wypełnienie kwestionariuszy.

Oprócz pacjentów, kolejnymi źródłami danych dla UK MS Register są kliniczne bazy szpitali National Health Service (NHS) oraz dane z podstawowej opieki zdrowotnej i od lekarzy praktykujących prywatnie $[38,39]$. Twórcy projektu uważają, że ten potrójny system rejestracji pozwoli objąć raportem większość pacjentów i zweryfikować przypadki niepewnych lub błędnych rozpoznań [38]. Projekt spotkał się z dużym zainteresowaniem i we wrześniu 2012 r. zarejestrowanych było już ponad 9500 użytkowników [39]. Na bieżąco można śledzić rozwój rejestru, szukać odpowiedzi na najczęściej zadawane pytania lub zapoznawać się z okresowo publikowanymi biuletynami.

\section{Rejestry międzynarodowe}

European Database for Multiple Sclerosis (EDMUS) jest kontynuacją powstałej w 1976 r. we Francji Lyon MS Database $[40,41]$. Rejestr obejmował początkowo Lyon i Burgundię, by w krótkim czasie rozszerzyć się na cała Francję i przyległe kraje. Dane są zbierane od neurologów zajmujących się leczeniem SR i rejestrowane za pomocą systemu komputerowego. Już w momencie wprowadzania są automatycznie sprawdzane pod względem poprawności i kompletności. Gromadzone informacje dotyczą danych socjodemograficznych, historii choroby (początek, liczba rzutów), badań laboratoryjnych i obrazowych oraz leczenia [42]. Przynajmniej raz w roku aktualizowane są dane $\mathrm{z}$ badania neurologicznego i ocena niesprawności w EDSS. EDMUS zapewnia regularne szkolenia dla lekarzy, prowadzi rozsądną politykę informacyjną o programie i kusi przyjaznym dla użytkownika interfejsem. Software jest systematycznie aktualizowany i dostępny w sześciu wersjach językowych (francuskiej, angielskiej, niemieckiej, włoskiej, hiszpańskiej i portugalskiej). W bazie zarejestrowanych jest ponad 36 tys. pacjentów z Francji. Liczba ta systematycznie wzrasta, program intensywnie się rozwija, a intencją autorów jest, by EDMUS stał się projektem ogólnoeuropejskim [30]. W lipcu 2012 r. programem EDMUS posługiwały się już 283 ośrodki z 41 krajów całego świata. Program można pobrać odpłatnie ze strony http://www.edmus.org/ [43].

MSBase - międzynarodowy rejestr internetowy SR - został powołany w 2004 r. [44]. Ten ogólnoświatowy projekt jest finansowany przez MSBase Foundation z siedzibą w Melbourne (Australia), a zarządzany przez International Scientific Advisory Board, w którego skład wchodzą przedstawiciele 11 krajów (głównie Australii, Kanady, Argentyny, Izraela i Stanów Zjednoczonych). MSBase została stworzona w celu maksymalnego ułatwienia zbierania danych na temat chorych na SR oraz w celu oceny sytuacji epidemiologicznej, co jest możliwe jedynie dzięki narzędziom opartym na wielotysięcznych bazach danych. Anonimowe dane o pacjentach wprowadzane są za pomocą strony internetowej www.msbase. org przez lekarzy uczestniczących w projekcie. Każdy pacjent musi wyrazić pisemną zgodę. Jakość oceny neurologicznej jest gwarantowana przez certyfikat kompetencji EDSS, który jest wymagany od zarejestrowanych neurologów. Aby po raz pierwszy wprowadzić pacjenta do MSBase, należy się zarejestrować, używając własnego hasła, wprowadzić unikalny kod pacjenta, płeć, datę urodzenia, datę pojawienia się objawów SR, datę rozpoznania SR potwierdzonego przez badania, określić postać SR, aktualny EDSS, wprowadzić daty przeprowadzonych badań za pomocą rezonansu magnetycznego (RM), płynu mózgowo-rdzeniowego i potencjałów wywołanych oraz daty rzutów. Kolejne wizyty są wymagane co najmniej raz w roku. Kluczowe jest wprowadzanie każdego rzutu i jego leczenia, terapii SR, wyników EDSS i badań diagnostycznych. Neurolodzy uczestniczacy w projekcie mogą korzystać $\mathrm{z}$ analiz statystycznych dotyczących wprowadzonych przez siebie pacjentów i porównywać ich z cała grupą [44-46]. MSBase daje również możliwość prowadzenia mniejszych badań, niezależnie od statystyk dotyczących całej grupy. Ustalany jest temat badawczy, a do współpracy zapraszani są inni uczestnicy. Obecnie prowadzone są m.in. następujące badania: Familial MS, Pediatric $M S$, Cognitive and psychiatrics impairment in RRMS, Vitamin D 
add-on therapy in RRMS [47]. We wrześniu 2012 r. w bazie zarejestrowanych było ponad 20 tys. pacjentów ze SR z 29 krajów (Polska nie bierze udziału w rejestrze) [47].

MSBase oparta jest na programie iMED ${ }^{\circledR}($ Electronic Multiple Sclerosis Patient Clinical Database) zaprojektowanym przez Samira Mechatiego i opatentowanym przez Serono International SA [48]. Program jest udostępniany bezpłatnie, był wielokrotnie aktualizowany i ma 10 wersji językowych (ostatnio dodano wersję fińską, holenderską i rosyjską), nie ma jednak wersji polskiej. Obecnie jest używany przez ok. 500 ośrodków leczenia SR na całym świecie (szpitalne bazy danych) i stanowi podstawę dużych narodowych (Italian MS Database Network) czy globalnych rejestrów SR (MSBase).

EUReMS (European Register for Multiple Sclerosis Europejski Rejestr Stwardnienia Rozsianego) jest trzyletnim projektem finansowanym z Programu Zdrowia Publicznego Unii Europejskiej. Projekt został zainicjowany przez Europejską Platformę Stwardnienia Rozsianego (European Multiple Sclerosis Platform - EMSP) zrzeszającą 38 stowarzyszeń ds. SR w 34 krajach Europy [49]. Celem projektu jest opracowanie jednolitej europejskiej metody zbierania danych dla oszacowania sytuacji epidemiologicznej, ocena klinicznych, zdrowotnych i ekonomicznych skutków terapii immunomodulujących SR oraz określenie życiowych perspektyw osób chorujących na SR [49].

Pilotażową fazę rejestru o nazwie MS-ID (Multiple Sclerosis Information Dividend) rozpoczęto w $2007 \mathrm{r}$. Uczestniczyło w nim 6 ośrodków europejskich (z Polski Centrum Rehabilitacji w Bornem Sulinowie) [50]. Przez 6 miesięcy zebrano dane o 547 pacjentach, które potwierdziły, że EUReMS może być bardzo użytecznym instrumentem w skali ogólnoeuropejskiej [50]. W celu zintegrowania już istniejących europejskich rejestrów narodowych podjęto prace nad standaryzacją wprowadzanych danych i stworzeniem jednolitego szablonu.

EUReMS zainicjował działalność 1 lipca 2011 r., ale na razie trwa faza przygotowawcza. Do czerwca 2014 r. planuje się zebranie danych z 10 krajów (w tym Polski), a w przyszłości ze wszystkich państw europejskich, również tych, które nie prowadzą własnych rejestrów [51]. Szczególnie ważnym partnerem projektu EUReMS ma być European Database for Multiple Sclerosis (EDMUS), która zebrała dotychczas dane z ponad 40 krajów. Różnica między rejestrami polega na tym, że EDMUS koncentruje się głównie na danych klinicznych zbieranych przez lekarzy, podczas gdy EUReMS jest bardziej zorientowany na samoocenę pacjenta [51].

\section{Polskie badania i projekty epidemiologiczne}

Obecnie w Polsce nie prowadzi się systematycznego rejestru chorych na SR. W dotychczasowych badaniach epidemiologicznych dotyczących SR określano wskaźniki dla wybranych terenów i miast środkowo-zachodniej, północno-zachodniej oraz wschodniej Polski: Leszna, Gniezna, Szczecina, Tczewa, Szczecinka i Lublina [5-10]. Badania te objęły zaledwie ok. $10 \%$ powierzchni oraz populacji kraju. W latach 1981-1999 w Klinice Neurologii PAM w Szczecinie systematycznie prowadzony był przez Potemkowskiego rejestr chorych na SR obejmujący obszar województwa szczecińskiego sprzed reformy administracyjnej kraju. Rejestr zgromadzit dane 1211 pacjentów z lat 1960-1980 retrospektywnie, a z lat 1981-1999 prospektywnie i angażował lekarzy oddziałów neurologicznych Szczecina i Gryfic [8,9]. W pilotażowym badaniu przeprowadzonym w $2008 \mathrm{r}$. w 21 ośrodkach leczących SR zebrano dane o 3581 pa cjentach [11]. Analizowano profil demograficzny chorych, wywiad chorobowy SR, stopień niepełnosprawności, choroby współwystępujące, metody diagnostyczne i stosowane leczenie. Było to pierwsze ogólnopolskie badanie na tak szeroką skalę - obejmujące ok. $18 \%$ populacji chorych [11]. Tym samym autorzy sugerują, po przeliczeniu danych, że całkowita liczba chorych na SR w Polsce wynosi ok. 20 tys. Poza tym krótkotrwałość projektu (8 miesięcy) nie pozwala na wyciagnnięcie wniosków na temat naturalnego przebiegu choroby, tempa postępu niepełnosprawności czy wpływu terapii modyfikującej przebieg SR.

W celu obserwacji długoterminowej określonej populacji (województwa świętokrzyskiego) z dniem 1 stycznia 2012 r. rozpoczęto zbieranie danych do Śrwię tokrzyskiego Rejestru Chorych ze Stwardnieniem Rozsianym - REJSM. Celem projektu jest ocena sytuacji epidemiologicznej w zakresie podstawowych wskaźników demograficznych. Uzyskano zgodę Komisji Etyki na prowadzenie rejestru.

Do udziału zostały zaproszone wszystkie oddziały neurologii, poradnie i prywatne gabinety neurologiczne z województwa świętokrzyskiego. Badanie pilotażowe zaplanowane jest na okres roku, by następnie stać się rejestrem długoterminowym. Zebrane dane wprowadzane są przez lekarza neurologa do programu komputerowego, który powstał jako praca magisterska afiliowana przez Akademię Górniczo-Hutniczą w Krakowie. Program wykorzystuje infrastrukturę informatyczną AGH, został nieodpłatnie udostępniony do celów 
naukowo-badawczych i ma wszelkie wymagane zabezpieczenia gwarantujące bezpieczeństwo wprowadzanych danych. Administrator programu rejestruje w systemie wszystkich chętnych do wspólpracy i nadaje im login i hasło. Dane do systemu mogą wprowadzać tylko zarejestrowani użytkownicy. Każdy pacjent musi wyrazić zgodę na udział w rejestrze. Wprowadzane informacje są anonimowe, $z$ wyjątkiem PESEL, który w rozumieniu prawa nie jest daną osobową i nie wymaga zgody na przetwarzanie. Pozwala to uniknąć wielokrotnego wprowadzania tego samego pacjenta, ponieważ program automatyczne blokuje wprowadzenie tego samego numeru PESEL. Program może być zainstalowany na lokalnym komputerze z dostępem do internetu po uzyskaniu od administratora hasła dostępu.

Moduł główny programu zawiera podstawowe dane demograficzne, takie jak: wiek, płeć, stan rodzinny, miejsce zamieszkania, wykształcenie, wywiad rodzinny, oraz dane związane bezpośrednio $z$ chorobą: pierwsze objawy, data rozpoznania, postać choroby, choroby wspólistniejące, występowanie rzutów, badania dodatkowe (RM, badanie płynu mózgowo-rdzeniowego, potencjały wywołane), rodzaj leczenia. W module oceny klinimetrycznej najważniejsza i obowiązkowa dla każdego pacjenta jest ocena EDSS (stopień niesprawności). Dodatkowo istnieje możliwość dokładniejszej oceny i śledzenia postępu choroby w czasie poprzez ocenę MSFC (złożony wskaźnik funkcji - MS Functional Composite), zaburzeń widzenia (Visual Function Test - VFT, oraz Symbol Digit Modalities Test - SDMT), zmęczenia i depresji (skala ciężkości zmęczenia, Fatigue Severity Scale FSS, zmodyfikowana skala oddziaływania zmęczenia Modified Fatigue Impact Scale - MFIS, skala depresji Becka, Beck Depression Inventory - BDI). Taka rozbudowana ocena może być szczególnie przydatna dla ośrodków prowadzących badania kliniczne. Aplikacje zawarte w module statystyk i aktualnych wyników generowane są automatycznie po wcześniejszym wprowadzeniu danych.

Rejestr systematycznie się rozrasta i autorzy sądzą, że zgromadzone dane pozwolą wkrótce na oszacowanie wskaźników epidemiologicznych z terenu całego województwa oraz precyzyjne określenie potrzeb pacjentów w zakresie leczenia i pomocy społecznej. W dalszej perspektywie możliwa będzie ocena wpływu terapii modulującej przebieg choroby, tempa przebiegu choroby i jej oddziaływania na jakość życia. Program został zbudowany z myślą o współpracy z projektem EUReMS i po pewnych przeróbkach może być $z$ nim w pełni kompatybilny. Twórcy programu mają nadzieję na jego roz- powszechnienie w skali kraju i udostępniają go nieodpłatnie wszystkim zainteresowanym.

\section{Podsumowanie}

Rejestry są potencjalnym źródłem ogromnej wiedzy o populacji chorych na SR i dają wartościowy wgląd w długoterminowy przebieg choroby [30,52]. Wieloletnie, prospektywne, wieloośrodkowe zbieranie danych może prowadzić do lepszego zrozumienia naturalnego przebiegu SR i określenia czynników prognostycznych choroby [29]. Kluczowe wnioski z rejestrów dotyczą szybkości postępu i czynników ryzyka niesprawności, towarzyszących chorób oraz zmiany długości życia związanej z chorobą. Duże znaczenie ma też długoterminowa obserwacja efektywności leczenia lekami modyfikującymi przebieg choroby i rejestracja chorych z CIS, co pomoże określić częstość jego występowania, a także śledzić zmiany chorobowe w czasie [52,53]. Dane zebrane w rejestrach mogą być przydatne w analizach farmakoekonomicznych. Sugeruje się wyznaczenie punktu końcowego w rejestrach na EDSS 6, gdyż osiągnięcie tego poziomu niesprawności, przy dalszej obserwacji nie wnosi istotnych danych epidemiologicznych, a znacznie wydłuża czas trwania rejestru $[29,30]$. Zaobserwowano, że postęp niesprawności już po osiagnięciu 4 punktów w EDSS następuje w przewidywalny sposób, niezależnie od przebiegu choroby (postać pierwotnie postępująca czy nawracająco-zwalniająca) i czasu od zachorowania [29].

Rejestry mają również wady. Obejmują często różne grupy pacjentów, zmienny jest zakres wprowadzanych danych i różne ich definicje, co utrudnia porównywanie wyników i analizy epidemiologiczne $[53,54]$. Bardzo istotne jest opracowanie metodologii, która jasno sprecyzuje kryteria gromadzenia danych, a program ich rejestracji będzie łatwy w obsłudze i niezbyt czasochłonny. Pewnym ograniczeniem jest brak możliwości kontroli jakości wprowadzanych danych oraz prawdopodobna selekcja, gdy badacze sami decydują o udziale pacjenta $\mathrm{w}$ rejestrze (physician-driven registries). Może wówczas zabraknąć pacjentów zbyt niesprawnych (nie trafiają do lekarza) lub pacjentów z łagodnym przebiegiem choroby, niewymagających wizyt lekarskich lub unikających kontaktów z systemem opieki zdrowotnej [29]. Problemu nie rozwiązują również internetowe bazy danych, gdzie pacjenci sami się rejestrują i odpowiadają on-line na pytania kwestionariuszowe (patient-driven databases). Nie wszyscy bowiem mają dostęp do internetu, potrafią 
posługiwać się komputerem, a niektórzy są zbyt niesprawni, by aktywnie uczestniczyć w rejestrze [29].

Mimo tych wszystkich ograniczeń bazy danych są niezastąpionym instrumentem $\mathrm{w}$ badaniach epidemiologicznych i należy dążyć do tego, aby wkrótce również w Polsce powstał narodowy rejestr chorych na SR.

\section{Oświadczenie}

Autorzy zgłaszają brak konfliktu interesów.

\section{Piśmiennictwo}

1. Selmaj K. Stwardnienie rozsiane. Termedia, Poznań 2006.

2. Rosati G. The prevalence of multiple sclerosis in the world: an update. Neurol Sci 2001; 22: 117-139.

3. Cendrowski W. Neuroepidemiologia kliniczna. Volumed, Wrocław 1997.

4. Potemkowski A. Stwardnienie rozsiane w świecie i w Polsce ocena epidemiologiczna. Aktualn Neurol 2009; 9: 91-97.

5. Wender M., Kowal P., Pruchnik-Grabowska D. i wsp. Epidemiologia stwardnienia rozsianego na terenie Wielkopolski. Przegl Epidemiol 1986; 40: 387-397.

6. Wender M., Pruchnik-Grabowska D., Hertmanowska H. i wsp. Zapadalność na stwardnienie rozsiane na terenie kilku województw zachodniej Polski. Zdrowie Publiczne 1994; 95: 531-536.

7. Fryze W., Obiedziński R. Występowanie stwardnienia rozsianego wśród mieszkańców miasta Tczew położonego na północy Polski. Neurol Neurochir Pol 1996; supl. 3: 77.

8. Potemkowski A. Analiza epidemiologiczna stwardnienia rozsianego w województwie szczecińskim: ocena zachorowalności i chorobowości w latach 1993-1995. Neurol Neurochir Pol 1999; 33: 575-585.

9. Potemkowski A., Stankiewicz J., Brzozowski S. i wsp. Analiza epidemiologiczna stwardnienia rozsianego w regionie Szczecina w latach 1960-2004. Neurol Neurochir Pol 2005; 39 (supl. 2): 301-302.

10. Łobińska A., Stelmasiak Z. Wybrane epidemiologiczne aspekty stwardnienia rozsianego w populacji miasta Lublina. Neurol Neurochir Pol 2004; 38: 361-366.

11. Kułakowska A., Bartosik-Psujek H., Hożejowski R. i wsp. Selected aspects of the epidemiology of multiple sclerosis in Poland a multicentre pilot study. Neurol Neurochir Pol 2010; 44: 443-452.

12. Koch-Henriksen N., Hyllested K. Epidemiology of multiple sclerosis: incidence and prevalence rates in Denmark 1948-64 based on the Danish Multiple Sclerosis Registry. Acta Neurol Scand 1988; 78: 369-380.

13. Koch-Henriksen N. The Danish Multiple Sclerosis Registry: a 50-year follow-up. Mult Scler 1999; 5: 293-296.

14. Koch-Henriksen N., Rasmussen S., Stenager E. i wsp. The Danish Multiple Sclerosis Registry. History, data collection and validity. Dan Med Bull 2001; 48: 91-94.

15. Koch-Henriksen N., Stenager E. Brønnum-Hansen H. Studies based on the Danish Multiple Sclerosis Registry. Scand J Public Health 2011; 39 (7 supl.): 180-184.
16. Sorensen P.S., Koch-Henriksen N., Ravnborg M. i wsp. Im munomodulatory treatment of multiple sclerosis in Denmark: a prospective nationwide survey. Mult Scler 2006; 12: 253-264.

17. Myhr K.M., Grytten N., Aarseth J.H. i wsp. The Norwegian Multiple Sclerosis National Competence Centre and National Multiple Sclerosis registry - a resource for clinical practice and research. Acta Neurol Scand 2006; 183 (Suppl): 37-40.

18. Landtblom A.M., Stawiarz L., Ahlgren C. i wsp. The National Swedish MS Register detects an unexpectedly high prevalence in Sweden. Mult Scler 2007; 13 (supl. 2): 104.

19. Ahlgren C., Odén A., Lycke J. High nationwide prevalence of multiple sclerosis in Sweden. Mult Scler 2011; 17: 901-908.

20. Trojano M., Granieri E., Rosati G.; MSDN Study Group. The Multiple Sclerosis Database Network (MSDN): an Italian source of valuable data for clinical and research studies. J Neurol 2003; 250: 37.

21. Trojano M., Paolicelli D., Lepore V. i wsp. Italian Multiple Sclerosis Database Network. Neurol Sci 2006; 27 (supl. 5): S358-S361.

22. Trojano M. Can databasing optimise patient care? J Neurol 2004; 251 (supl. 5): 79-82.

23. Schröder M. MUSIS 2.0 - Multiple Sclerosis Information System: an easy-to-use-database to improve the care of patients with multiple sclerosis. Mult Scler 1999; 5: 299-301.

24. Wolinsky J.S.; PROMise trial group. The PROMise trial: data review and progress report. Mult Scler 2004; 10: 65-71.

25. Mancardi G.L., Uccelli M.M., Sonnati M. i wsp. The SMile Card: a computerised data card for multiple sclerosis patients. Smile Card Scientific Board. Neurol Sci 2000; 21: 93-98.

26. Flachenecker P., Zettl U.K., Gotze U. i wsp. MS-Register in Deutschland: abschliessende Ergebnisse der Pilotphase. Neurol Rehabil 2007; 13: 193-200.

27. Stuke K., Flachenecker P., Zettl U.K. i wsp. Symptomatology of MS: results from the German MS Registry. J Neurol 2009; 256: 1932-1935.

28. Sadovnick A.D., Ebers G.C., Wilson R.W. i wsp. Life expectancy in patients attending multiple sclerosis clinics. Neurology 1992; 42: 991-994.

29. Hurwitz B.J. Analysis of current multiple sclerosis registries. Neurology 2011; 76 (1 supl. 1): 7-13.

30. Hurwitz B.J. Registry studies of long-term multiple sclerosis outcomes: description of key registries. Neurology 2011; 76 (1 supl. 1): S3-6.

31. Studney D., Lublin F., Marcucci L. i wsp. MS COSTAR: a computerized record for use in clinical research in multiple sclerosis. J Neuro Rehab 1993; 7: 145-152.

32. Paty D., Studney D., Redekop K. i wsp. MS COSTAR: a computerized patient record adapted for clinical research purposes. Ann Neurol 1994; 36 (supl.): 134-135.

33. Vollmer T.L., Ni W., Stanton S., Hadjimichael O. The NARCOMS patient registry: a resource for investigators. Int J MS Care 1999; 1: 12-15.

34. Lo AC., Hadjimichael O., Vollmer T.L. Treatment patterns of multiple sclerosis patients: a comparison of veterans and non-veterans using the NARCOMS registry. Mult Scler 2005; 11: 33-40.

35. Marrie R.A., Cutter G., Tyry T. i wsp. Validation of the NARCOMS registry: diagnosis. Mult Scler 2007; 13: 770-775.

36. http://www.narcoms.org 
37. Jacobs L.D, Wende K.E., Brownscheidle C.M. i wsp. A profile of multiple sclerosis: the New York State Multiple Sclerosis Consortium. Mult Scler 1999; 5: 369-376.

38. Ford D.V., Jones K.H., Middleton R.M. i wsp. The feasibility of collecting information from people with Multiple Sclerosis for the UK MS Register via a web portal: characterising a cohort of people with MS. BMC Med Inform Decis Mak 2012; 12: 73-80.

39. http://www.ukmsregister.org

40. Confavreux C., Compston D.A., Hommes O.R. i wsp. EDMUS, a European database for multiple sclerosis. $J$ Neurol Neurosurg Psychiatry 1992; 55: 671-676.

41. Confavreux C. Establishment and use of multiple sclerosis registers - EDMUS. Ann Neurol 1994; 36 Suppl: S136-S139.

42. Confavreux C., Vukusic S., Moreau T. i wsp. Relapses and progression of disability in multiple sclerosis. $N$ Engl J Med 2000; 343: 1430-1438.

43. http://www.edmus.org/

44. Butzkueven H., Chapman J., Cristiano E. i wsp. MSBase: an international, online registry and platform for collaborative outcomes research in multiple sclerosis. Mult Scler 2006; 12: 769-774.

45. Hughes S., Spelman T., Trojano M. i wsp. The Kurtzke EDSS rank stability increases 4 years after the onset of multiple sclerosis: Results from the MSBase Registry. J Neurol Neurosurg Psychiatry 2012; 83: 305-310.

46. Kister I., Chamot E., Cutter G. i wsp. Increasing age at disability milestones among MS patients in the MSBase Registry. J Neurol Sci 2012; 318: 94-99.

47. http://www.msbase.org

48. Mechati S., Peyro-St-Paul H. iMed: a new electronic database for monitoring patients with multiple sclerosis. Mult Scler 2001; $7: 31$.

49. http://www.emsp.org/index.php?option $=$ com_content\&view $=$ article\&id $=138$ :about-theeurems-project

50. Flachenecker P., Khil L., Bergmann S. i wsp. Development and pilot phase of a European MS register. J Neurol 2010; 257: 1620-1627.

51. Making EUReMS count for people with multiple sclerosis. Lancet Neurol 2011; 10: 865.

52. Flachenecker P., Stuke K. National MS registries. J Neurol 2008; 255 (supl. 6): 102-108.

53. Devonshire V. Clinical databases in MS: patient management and research. Int MSJ 2001; 8: 57-66.

54. Weinshenker B. Databases in MS research: pitfalls and promises. Mult Scler 1999; 5: 206-211. 